\title{
Preliminary Weather Report of Monsoon Season, 2010 across Nepal
}

\section{Climate Section}

\author{
Department of Hydrology and Meteorology \\ Ministry of Environment \\ Babarmahal, Kathmandu \\ Email:sarajubaidya@yahoo.com,ira_kadel@yahoo.com
}

\begin{abstract}
Monsoon is the main rain bearing season contributing about $80 \%$ of the total annual rainfall in the country. This year, the onset of monsoon in Nepal occurred on 17th June delayed by 7 days from the normal onset date of 10th June and retreated from Nepal on 1st October, 8 days later than the normal withdrawal date of 23rd September.
\end{abstract}

Based on preliminary data of 30 stations, the monsoon season 2010 is characterized by wet conditions in northwestern parts of Western Region and adjoining parts of Mid Western Region with large parts of the country receiving normal (average from 1971-2000) to above normal rainfall. Southeastern parts of Central Region and Surkhet in Mid Western region, however, recorded below normal rainfall. Monsoon season started as drier than normal in most parts in June, but significant rainfall occurred in July, August and September resulting normal to above normal in most parts of the country. The spatial distribution of rainfall as percentage of normal showed normal to above normal rainfall in July, August and September throughout the country excluding few small regions here and there. Total seasonal rainfall varied from $296.8 \mathrm{~mm}$ recorded in Jomsom to $4918.0 \mathrm{~mm}$ in Lumle. Pokhara broke the extreme 24-hr July rainfall record of $243.6 \mathrm{~mm}$ by recording 262.1 $\mathrm{mm}$ on 10-11th July. Floods and landslides during the monsoon season associated with heavy rainfall caused about 150 deaths and 51 injured affecting 46 districts from 22 June to 12 September 2010 (Source: Nepal Red Cross Society, Situation Monitoring Report, Update-33).

Monsoon season 2010 was warmer than normal. Average seasonal mean temperature varied from about $17^{\circ} \mathrm{C}$ to above $30^{\circ} \mathrm{C}$. Spatial distribution of mean temperature anomaly depicted above normal in most parts of the country including warming by more than $1^{\circ} \mathrm{C}$ in large parts of Eastern Region and western parts of Far Western Region. During the beginning of the season in June, temperature anomalies of +0.5 to above $+2{ }^{\circ} \mathrm{C}$ were observed in large parts of the country. In July, large parts of the country experienced normal to below normal temperature; however, the anomalies were above normal over southern parts of Eastern and Central Regions and Northern parts of Far Western Regions. Positive temperature anomalies extended in area with higher values in August in comparison to July. In September, most parts of the country remained warmer than normal particularly by more than $1^{\circ} \mathrm{C}$ in the Eastern Region. However, normal to below normal temperature covered large areas of Western Region and southern belt of Far Western Region. Following stations broke the highest maximum and the lowest minimum temperature records for the particular months during the season. 


\begin{tabular}{|c|c|c|c|c|}
\hline Month & Station & Parameter & New Record & Previous Record \\
\hline June & Dhankuta & Maximum Temperature & $31.6^{\circ} \mathrm{C}$, June 11, 2010 & $31.2^{\circ} \mathrm{C}$, June 24,2009 \\
\hline \multirow{2}{*}{ July } & Nepalgunj Airport & Minimum Temperature & $19.8^{\circ} \mathrm{C}$, July 14,2010 & $21.8^{\circ} \mathrm{C}$, July 4, 2009 \\
\hline & Simara Airport & Maximum Temperature & $38.8^{\circ} \mathrm{C}$, July 23,2010 & $38.5^{\circ} \mathrm{C}$, July 14,2009 \\
\hline \multirow{3}{*}{ August } & Nepalgunj Airport & Minimum Temperature & $\begin{array}{c}20.4^{\circ} \mathrm{C} \text {, August } 21, \\
2010\end{array}$ & $\begin{array}{c}22.1^{\circ} \mathrm{C} \text {, August } 14, \\
2001\end{array}$ \\
\hline & Kathnandu Airport & Maximum Temperature & $\begin{array}{c}32.6^{\circ} \mathrm{C} \text {, August } 18, \\
2010\end{array}$ & $\begin{array}{c}32.5^{\circ} \mathrm{C} \text {, August 09, } \\
2008\end{array}$ \\
\hline & Surkhet & Maximum Temperature & $\begin{array}{c}34.5^{\circ} \mathrm{C} \text {, August 06, } \\
2010 \\
\end{array}$ & $\begin{array}{c}34.2^{\circ} \mathrm{C} \text {, August } 9 \text {, } \\
2008\end{array}$ \\
\hline
\end{tabular}

